\title{
Pengenalan Sejarah Pada Anak Usia Dini dengan Metode Mendongeng
}

Oleh:

Dita Hendriani, M.A

dithacute_r7@yahoo.com

\begin{abstract}
ABSTRAK
Bercerita atau mendongeng merupakan warisan budaya yang sudah lama kita kenal, bahkan dijadikan sebagai kebiasaan atau tradisi bagi para orangtua untuk menidurkan anak-anaknya. Sebagian besar orang tua dan guru jarang mendongeng kepada anak karena kurangnya buku cerita yang sesuai perkembangan anak dan terbatasnya media pendukungnya. Pendampingan kepada orang tua dan guru dalam meningkatkan budaya membaca permulaan pada anak usia dini dilaksanakan KB Al Naba, Arjowinangun, Kota Malang pada tanggal 22 September 2019 dengan jumlah peserta 40 orang tua dan guru. Hasil monitoring adalah anak menjadi lebih tertarik untuk mendengarkan dongeng, lebih tertib dan tenang dalam proses belajar mengajar di KB Al Naba. Beberapa anak tertarik pada buku cerita dan bisa menceritakan cerita bergambar sendiri. Harapannya kegiatan pendampingan ini bisa dilaksanakan dalam skala yang lebih luas dengan materi yang lebih berkembang misalnya tentang cara membuat suara yang berbeda, ekspresi dalam mendongen serta Dongeng Sejarah dan Kisah Kepahlawanan
\end{abstract}

Kata Kunci : dongeng, boneka tangan, buku cerita, sejarah, kisah pahlawan 


\section{A. Konteks Kegiatan}

Membaca merupakan suatu keterampilan berbahasa yang sangat penting peranannya dalam kehidupan. Membaca mempunyai peranan penting dalam melahirkan generasi penerus bangsa yang cerdas, kreatif, dan kritis. Dengan membaca seseorang mendapat pengetahuan dan informasi dari berbagai penjuru dunia. Menurut Poerwadarminta membaca merupakan suatu kegiatan melihat tulisan dan mengerti atau dapat melisankan apa yang tertulis. ${ }^{1}$ Manusia yang berbudaya dan berpendidikan menjadikan membaca menjadi suatu kebutuhan dalam berkomunikasi. Pada dasarnya kemampuan dan keterampilan membaca menjadi suatu kebutuhan yang harus dipenuhi. Sehingga kemampuan membaca harus dilatih sejak dini. Kegiatan membaca permulaan dimulai dari usia dini.

Dilansir dari data penelitian yang dilakukan United Nations Development Programme (UNDP), tingkat pendidikan berdasarkan Indeks Pembangunan Manusia (IPM) di Indonesia masih tergolong rendah, yaitu $14,6 \%$. Persentase ini jauh lebih rendah dibandingkam Malaysia yang mencapai angka 28\% dan Singapura yang mencapai angka $33 \%$.

Faktor utama yang menyebabkan minat baca masyarakat Indonesia masih rendah adalah karena kebiasaan membaca yang belum ditanamkan sejak anak usia dini. Role model anak di keluarga adalah anak-anak akan mengikuti kebiasaan dari orang tua artinya bahwa orang tua haruslah menjadi figur. Oleh karena itu, peranan

\footnotetext{
${ }^{1}$ W.J.S Poerwadarminta,1984, Kamus Umum Bahasa Indonesia, Jakarta. PN Balai. Pustaka.
}

orang tua untuk mengajarkan kebiasaan membaca adalah penting dalam meningkatkan kemampuan literasi anak. ${ }^{2}$

Pentingnya mengenalkan peristiwa sejarah pada anak usia dini adalah agar anak mengetahui kisah-kisah heroik para pahlawan di masa lalu, untuk kemudian diambil hikmah/ibrahnya sehingga menjadi pelajaran karakter bagi anak tersebut. Anak akan meneladani sifat positif dari para pahlawan dan menumbuhkan minat literasi anak akan cerita sejarah.

Selain pendidikan formal sebagai penunjang perkembangan literasi anak yang dilakukan guru di sekolah, pendidikan informal juga mempengaruhi perkembangan literasi anak, khususnya orang tua. Hal tersebut dikarenakan pendidikan literasi yang dilakukan di sekolah dan di rumah saling mendukung. Ketika pembelajaran literasi dilakukan di rumah, orang tua mengulang pengetahuan anak pada literasi yang telah diajarkan di sekolah, dengan cara pemberian rangsangan pada anak guna memaksimalkan perkembangan literasi anak.3

Menurut Snow (dalam Hoff, 2005) bahwa anak yang berusia $2-5$ tahun sudah bisa menunjukkan kemampuan literasinya secara pesat. Saat berusia $0-3$ tahun, seharusnya anak dapat mengenali

\footnotetext{
2 Nurul Iswari. (2017). Ini Penyebab Rendahnya Minat Baca di Indonesia. Media Online Kumparan, https://kumparan.com/nuruliswari/ini-penyebab-rendahnya-minat-baca-diindonesia-1504967041086. Diakses 20 Juli 2019.

3 Pradipta, G. A. (2011). Keterlibatan orang tua dalam proses mengembangkan literasi dini anak usia paud di Surabaya. Jurnal Unair,1(3),1-9.
} 
buku dengan mengidentifkasi sampul buku, menuliskan huruf, mendengarkan cerita, berpura-pura membaca. Sedangkan, anak yang mempunyai usia antara $3-4$ tahun telah mampu mengenali tulisan yang simpel, mampu mengidentifikasi bunyi bahasa dengan notasi yang berbeda, mengkomparasi cerita di buku dengan yang terjadi atau kenyataan, tertarik untuk membaca buku. Pada anak yang berusia 5 tahun sudah mampu memprediksian alur cerita dalam buku, menuliskan nama dan kata dengan dikte. ${ }^{4}$

$$
\text { Menurut Faris }
$$

membangkitkan, membina, dan memupuk minat siswa adalah tujuan dalam membaca permulaan. Terdapat siswa yang memiliki kemampuan membaca permulaannya baik sehingga dapat memengaruhi untuk membaca lebih lanjut. Kemampuan membaca permulaan akan menentukan tingkat kesulitan anak dalam pembelajaran. 5 Oleh sebab itu, guru harus memberikan kontribusi yang terbaik supaya siswa mendapatkan potensi kemampuan membaca yang baik.

Bercerita atau mendongeng merupakan warisan budaya yang sudah lama kita kenal, bahkan dijadikan sebagai kebiasaan atau tradisi bagi para orangtua untuk menidurkan anak-anaknya. Melalui cerita atau dongeng banyak hal tentang hidup dan kehidupan yang dapat kita informasikan kepada anak-anak. Begitu juga pesan-pesan moral dan nilai-nilai agama dapat kita tanamkan kepada anak-

\footnotetext{
${ }^{4}$ Widyaning Hapsari, Lisnawati Ruhaena, \& Wiwien Dinar Pratisti , Peningkatan Kemampuan Literasi Awal Anak Prasekolah melalui Program Stimulasi, Jurnal Psikologi. Volume 44, Nomor 3, 2017: hal 178

5 Mety Toding Bua, Anang Santoso, Muakibatul Hasanah, Jurnal Pendidikan, Vol. 1, No. 9, Bln September, Thn 2016, Hal 1749-1752
}

anak melalui tokoh-tokoh yang ada dalam cerita atau dongeng tersebut.

Kesibukan menjadi salah satu alasan kurangnya waktu orangtua untuk anakanaknya. Sebuah survei yang dilakukan pada 500 anak usia 3-8 tahun di Inggris mengungkapkan, hampir $2 / 3$ anak yang disurvei menginginkan orangtuanya meluangkan waktu untuk membacakan cerita sebelum mereka tidur, terutama oleh sang ibu. 6

Sampai saat ini kegiatan mendongeng sudah banyak ditinggalkan oleh para orangtua, karena dianggap merepotkan dan membuat mereka semakin lelah setelah seharian bekerja. Padahal manfaat mendongeng untuk anak sangat banyak seperti merekatkan hubungan orangtua dengan anak dan bisa membantu mengoptimalkan perkembangan psikologis dan kecerdasan anak secara emosional, mengembangkan daya imajinasi anak,meningkatkan keterampilan dalam berbahasa, dan membangkitkan minat baca anak. Jika ingin memiliki anak yang mempunyai minat baca yang baik, maka mendongeng adalah jalan menuju hasil tersebut. Dengan memberikan cerita dongeng anak-anak, maka anak-anak akan tertarik dan rasa penasaran ini membuat mereka ingin mencari tahu. Inilah dimana keinginan untuk membaca menjadi semakin meningkat. Dengan membacakan buku cerita yang menarik kepada anak

\footnotetext{
${ }^{6}$ Kompas.com "Manfaat Dongeng untuk Anak", https://lifestyle.kompas.com/read/2012/0 5/15/14183692/manfaat.dongeng.untuk.a nak.
} 
adalah cara paling mudah yang bisa dilakukan guru dan orangtua. ${ }^{7}$

Boneka tangan adalah boneka yang digerakkan dari bawah oleh seseorang yang tangannya dimasukkan ke bawah pakaian boneka tersebut. Boneka adalah suatu benda yang pada umumnya disukai oleh anak-anak, sehingga pemilihan boneka tangan ini dirasa sangat tepat karena dapat dengan mudah menarik perhatian anak. ${ }^{8}$ Orang tua dan guru bisa memakai boneka tangan untuk menyampaikan pesan. Sebab, anak akan mudah menangkap pesan dengan cara yang menyenangkan. Penggunaan media boneka tangan mendukung kegiatan pembelajaran yang aktif dan menyenangkan, sehingga tujuan pembelajaran dapat tersampaikan dengan baik. Sehingga anak-anak dapat memahami materi yang disampikan oleh guru.

Kota Malang adalah sebuah kota yang terletak di Provinsi Jawa Timur, Indonesia, kota terbesar kedua di Jawa Timur setelah Surabaya, dan kota terbesar ke-12 di Indonesia. Malang dikenal sebagai Kota Pendidikan, karena memiliki sejumlah perguruan tinggi ternama. Selain perguruan tinggi, ada beberapa SMU/MA, SMP/MTs, SD/MI yang namanya sudah terkenal hingga tingkat nasional bahkan internasional. Pendidikan PAUD di Kota Malang juga berkembang dengan pesat

\footnotetext{
${ }^{7}$ Winda Destiana Putri. Peran Penting Mendongeng untuk Anak dan Orangtua, Rabu 25 Feb 2015 13:36 WIB https://www.republika.co.id/berita/gayahidup/parenting/15/02/25/nkbbl2-peranpenting-mendongeng-untuk-anak-dan-orangtua

${ }^{8}$ Nana Sudjana dan Ahmad Rivai. Media

Pengajaran.Bandung: Sinar Baru

Algensindo.(2002:188).
}

dengan jumlah 779 lembaga PAUD terdiri dari 457 TK/RA, 145 KB, 21 TPA dan 156 SPS (Pos Paud) ${ }^{9}$

Kelompok Bermain (KB) Al Naba adalah PAUD yang beralamatkan di Perum Puskopad Puri Kartika Asri Kelurahan Arjowinangun Kecamatan Kedungkandang Kota Malang. KB Al Naba berdiri sejak 22 Agustus 2005 dengan usia peserta didik 2-4 tahun. Berdasarkan hasil wawancara dengan Kepala Sekolah KB Al Naba di Kelurahan Arjowinangun Kota Malang pada hari Kamis, 25 Juli 2019 diungkapkan bahwa sebagian besar guru jarang mendongeng kepada siswa karena kurangnya buku cerita yang sesuai perkembangan anak dan terbatasnya media pendukungnya, misalnya boneka jari dan boneka tangan. Sedangkan wawancara terhadap beberapa orang tua peserta didik juga menyampaikan bahwa orang tua sebenarnya sangat menginginkan mendongeng kepada anak sebelum tidur tetapi terkadang tidak punya ide mau bercerita tentang apa. Buku cerita sebagai sumber ide yang kualitasnya bagus dan sesuai dengan perkembangan anak, harganya sangat mahal sedangkan buku cerita yang murah terkadang ceritanya membosankan sehingga anak-anak tidak tertarik mendengarkan dongeng.

Dari latar belakang masalah tersebut maka kami melakukan Pendampingan kepada Orang Tua Dan Guru dalam Meningkatkan Budaya Membaca Permulaan pada Anak Usia Dini di KB Al Naba, Arjowinangun, Kota Malang

\section{B. Dasar Teori}

\footnotetext{
${ }^{9}$ Jumlah Data Satuan Pendidikan (Sekolah) Anak Usia Dini Per Kabupaten/Kota : Kota Malang online http://referensi.data.kemdikbud.go.id/index21.ph $p$ ?kode $=056100$ \&level $=2$
} 


\section{Membaca Permulaan}

"Membaca" dapat diartikam sebagai melihat serta memahami konten atau isi dari apa yang tertulis, atau mengeja dan melafalkan apa yang tertulis. 10 Membaca permulaan sebagai tahap awal yang penting dalam belajar membaca dengan memfokuskan kepada pengenalan simbol-simbol atau tanda-tanda yang berkaitan dengan huruf-huruf sehingga menjadi pondasi dasar kepada anak dalam melanjutkan ketahap membaca. ${ }^{11}$ Membaca permulaan dapat dikatakan sebagai membaca yang diajarkan secara terprogram dan sistematis kepada anak prasekolah.

\section{Anak Usia Dini}

Anak Usia Dini merupakan antara yang berusia antara 0-6 tahun. Di masa itulah, para ahli menyebutnya sebagai masa emas atau masa golden ages. Periode emas adalah masa dimana perkembangan otak pada anak mengalami pertumbuhan paling cepat sepanjang hidupnya. Otak adalah kunci utama bagi pembentukan kecerdasan anak. Pada anak pertumbuhan dan perkembangan otak akan mencapai $80 \%$ dan berkembang $20 \%$ saat mencapai usia dewasa. Itulah mengapa Montessori menyebutkan bahwa otak anak usia golden ages seperti spon yang siap menyerap berbagai informasi apapun yang mereka dapatkan. Walaupun

${ }^{10}$ (KBBI, 1999: 72)

11 Darwadi 2002 dalam Nurfalah, Upaya Meningkatkan Kemampuan Membaca Permulaan Melalui Pendekatan Proses pada Siswa Kelas II SDN 1 Wosu Kec. Bungku Barat Kab. Morowali, Jurnal Kreatif Tadulako Online Vol. 3 No. 1, hal 31 secara praktek, anak-anak seringkali tidak sempurna dalam menunjukkan kemampuannya. $^{12}$

\section{Peranan Orang Tua dan Guru}

Peranan Orang tua merupakan instrumen yang dimainkan oleh orang tua sebagai bentuk penguasaan terhadap kehidupan mereka dengan adanya keterlibatan pada perkembangan kehidupan anaknya. Pada studi pengembangan literasi, adanya keterlibatan pada orang tua dapat dilukiskan sebagai proses mentoring yang dilakukan oleh orang tua kepada anak-anaknya sebagai upaya pencapaian tujuan yang positif (Eisenberg, 2002).

Sedangkan peranan guru menurut Sardiman (2010) antara lain: a) seorang pendidik dan pembimbing; b) seorang demonstrator; c) sebagai mediator; d) sebagai fasilitator;e) sebagai evaluator. Mendongeng adalah sebuah senin bercerita yang menggambarkan peristiwa yang sebenarnya maupun berupa fiksi dan dapat disampaikan menggunakan gambar ataupun suara. ${ }^{13}$

\section{Pelaksanaan Pendampingan}

\section{Kondisi Lokasi KB Al Naba}

Kelompok Bermain Al Naba dimulakan pada 22 Agustus 2005 di Perum PUSKOPAD Puri Kartika Asri Arjowinangun. Pertama kali dioperasionalkan, dikepalai oleh Iis Sadiyyah lalu digantikan oleh Arina

\footnotetext{
12 Suyadi. (2010). Psikologi Belajar Anak Usia Dini. Yogyakarta : PEDAGOGIA

${ }^{13}$ Oliver, Serrat, Storytelling.2008. United States of America: ReedElsevier
} 
Wijayanti,SE Lilis Puspitosari, S.P., Elvanti Rahmania dan sejak tahun 2017 Kepala Sekolah kembali dipegang ole Lilis Puspitosari, S.P . Selama 15 tahun perjalanan KB Al Naba tetap pada tujuan semula yaitu sebagai kelompok bermain yang ramah dan perhatian kepada anak.

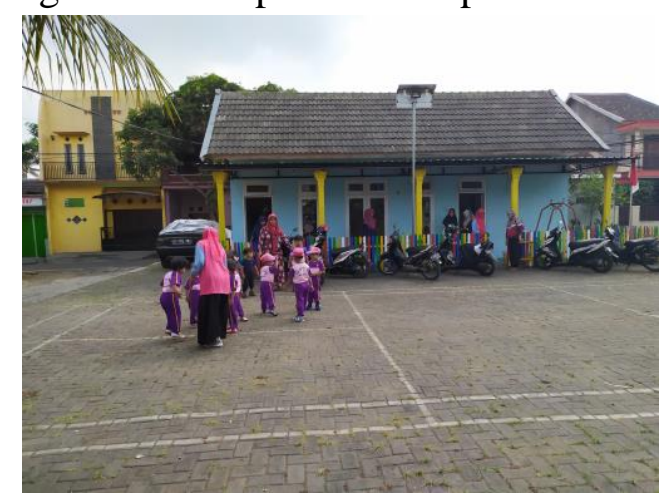

Gambar 4.1 Gedung KB Al Naba Nampak dari Depan

Identitas KB Al Naba adalah sebagai berikut :

\begin{tabular}{|l|l|l|}
\hline $\begin{array}{c}\text { No } \\
.\end{array}$ & \multicolumn{2}{|c|}{ Identitas Sekolah } \\
\hline 1. & Nama Sekolah & KB Al Naba \\
\hline 2. & N.I.S & - \\
\hline 3. & N.S.S & - \\
\hline 4 & NPSN & 69909939 \\
\hline 4. & Provinsi & Jawa Timur \\
\hline 5. & Otonomi & Daerah \\
\hline 6. & Kecamatan & Kedungkandang \\
\hline 7. & $\begin{array}{l}\text { Desa/ } \\
\text { Kelurahan }\end{array}$ & Arjowinangun \\
\hline 8. & $\begin{array}{l}\text { Jalan Dan } \\
\text { Nomor }\end{array}$ & $\begin{array}{l}\text { Perum Puskopad Puri } \\
\text { 09 }\end{array}$ \\
\hline 9. & Kode Pos & 65132 \\
\hline 10. & Telepon /Hp & 085655526335 \\
\hline 11. & Faksimile & RW \\
\hline 12. & Daerah & Kota \\
\hline 13. & $\begin{array}{l}\text { Status } \\
\text { Sekolah }\end{array}$ & Swasta \\
\hline 14. & $\begin{array}{l}\text { Kelompok } \\
\text { Sekolah }\end{array}$ & PAUD \\
\hline 15. & Status & - \\
\hline & & \\
\hline
\end{tabular}

\begin{tabular}{|c|c|c|}
\hline & $\begin{array}{l}\text { Akreditasi } \\
\text { /Tahun }\end{array}$ & \\
\hline 16. & $\begin{array}{l}\text { Surat } \\
\text { Keputusan/ Sk }\end{array}$ & $\begin{array}{l}421.1 / 3980 / 35.73 .301 / 2 \\
018\end{array}$ \\
\hline 17. & $\begin{array}{l}\text { Penerbit Sk } \\
\text { (Ditanda } \\
\text { Tangani Oleh) }\end{array}$ & $\begin{array}{l}\text { Dinas Pendidikan Kota } \\
\text { Malang (Kepala Dinas } \\
\text { Pendidikan Kota } \\
\text { Malang- Drs. Zubaidah, } \\
\text { MM) }\end{array}$ \\
\hline 18. & Tahun Berdiri & 2005 \\
\hline 19. & $\begin{array}{l}\text { Sk Yayasan } \\
\text { /Kemenhumh } \\
\text { am }\end{array}$ & $\begin{array}{l}\text { No } 228 \text { 2016/ } \\
\text { Ahu.0017674.Ah.01.04. } \\
\text { Tahun } 2016\end{array}$ \\
\hline 20. & $\begin{array}{l}\text { Kegiatan } \\
\text { Belajar } \\
\text { Mengajar }\end{array}$ & $\begin{array}{l}\text { Pagi ((Pukul 08.00 S.D } \\
\text { 10.00) }\end{array}$ \\
\hline & $\begin{array}{l}\text { Jumlah } \\
\text { Peserta Didik }\end{array}$ & 30 \\
\hline & $\begin{array}{l}\text { Jumlah } \\
\text { Rombel }\end{array}$ & 3 \\
\hline & Jumlah Guru & 4 \\
\hline 21. & $\begin{array}{l}\text { Status } \\
\text { Bangunan } \\
\text { Sekolah }\end{array}$ & Sewa \\
\hline 22. & $\begin{array}{l}\text { Luas } \\
\text { Bangunan } \\
\text { Dan Luas } \\
\text { Tanah }\end{array}$ & $100 \mathrm{M}^{2}$ \\
\hline 23. & $\begin{array}{l}\text { Lokasi } \\
\text { Sekolah }\end{array}$ & Dalam Perumahan \\
\hline 24. & $\begin{array}{l}\text { Jarak Ke } \\
\text { Pusat } \\
\text { Kecamatan }\end{array}$ & $3 \mathrm{Km}$ \\
\hline 25 . & $\begin{array}{l}\text { Jarak Ke } \\
\text { Pusat Otoda }\end{array}$ & $9 \mathrm{Km}$ \\
\hline 26. & $\begin{array}{l}\text { Terletak Pada } \\
\text { Lintasan }\end{array}$ & Kecamatan \\
\hline 27. & $\begin{array}{l}\text { Jumlah } \\
\text { Keanggotaan } \\
\text { Gugus }\end{array}$ & $8 \mathrm{TK} / \mathrm{KB} / \mathrm{SPS}$ \\
\hline 28. & $\begin{array}{l}\text { Organisasi } \\
\text { Penyelenggar } \\
\text { a }\end{array}$ & $\begin{array}{l}\text { Yayasan Al Naba Kota } \\
\text { Malang }\end{array}$ \\
\hline 29 & $\begin{array}{l}\text { Perjalanan/ } \\
\text { Perubahan } \\
\text { Sekolah }\end{array}$ & $\begin{array}{l}\text { KB Al Naba awalnya } \\
\text { bernaung di bawah } \\
\text { Lembaga }\end{array}$ \\
\hline
\end{tabular}




\begin{tabular}{|l|l|}
\hline & Pengembangan \\
& Pendidikan Insan \\
& Indonesia lalu mulai \\
& tahun 2016 LPPII \\
& berganti nama menjadi \\
& Yayasan Al Naba Kota \\
& Malang. \\
& Adapun alamat \\
& sebelumnya adalah \\
& Perum Puskopad Puri \\
& Kartika Asri B/11 Rt 01 \\
& Rw 09 berubah pada \\
& tahun 2018 menjadi \\
& Perum Puskopad Puri \\
& Kartika Asri RT 01 RW \\
& 09 Arjowinangun. \\
\hline
\end{tabular}

Visi Misi dan Tujuan KB Al Naba adalaah sebagai berikut :

a. Visi KB Al Naba adalah Menjadi lembaga pendidikan yang bisa mengantarkan anak didik melalui tahap-tahap perkembangannya \& berkepribadian Islam.

b. Misi KB Al Naba adalah : 1) mengembangkan lembaga pendidikan yang berdedikasi tinggi bagi anak usia dini, 2) membantu anak didik supaya sehat, cerdas, ceria, kreatif dan mandiri, 3) menumbuhkan sikap dan perilaku yang Islami

c. Tujuan KB Al naba adalah : 1) mampu merangsang perkembangan fisiknya, antara lain: menggunakan keterampilan gerak tubuh, melakukan ibadah, mengenal dan percaya kepada Tuhan YME dan mencintai sesama., 2) mampu merangsang perkembangan moral, antara lain: menggunakan bahasa untuk pemahaman bahasa pasif dan dapat berkomunikasi secara efektif yang bermanfaat dalam proses berpikir dan belajar, 3) mampu merangsang perkembangan kognitif, antara lain: berpikir logis, kritis, kreatif mengenal lingkungan alam, sosial, memberi alasan, berperan di masyarakat dan menghargai keragaman sosial budaya, 4) mampu merangsang perkembangan sosial anak, antara lain: peka terhadap irama, nada, birama, berbagai bunyi, bertepuk tangan, serta menghargai hasil karya yang kreatif, 5) Peningkatan kualitas kesehatan dan status gizi anak, melalui kegiatan PMT dan peningkatan pengetahuan dan pemahaman orang tua tentang tumbuh kembang anak.

\section{Pelaksanaan Pendampingan}

Pelaksanaan pendampingan terhadap KB Al Naba dilakukan sebagai berikut:

\section{Persiapan}

Mendiskusikan permasalahan yang terjadi dengan Kepala KB Al Naba untuk membangun kesepakatan bersama dalam perencanaan riset di MCD Sarinah.

Berdasarkan permasalahan di KB Al Naba ditemukan masalah yang ada dan yang lebih penting untuk diputuskan bersama adalah meningkatkan kemampuan orang tua dan guru dalam mendongeng dengan buku cerita dan boneka tangan. Hal ini, dilakukan guna merencanakan aksi atau solusi yang akan di putuskan dalam menyelesaikan permasalahan yang 
ada yaitu dengan Pendampingan terhadap orang tua dan guru dalam mendongeng dengan media buku cerita dan boneka tangan yang akan dilaksanakan pada tanggal 22 September 2019.

Sebagai persiapan untuk acara pendampingan tersebut maka dilakukan pengadaan terhadap boneka tangan dan buku cerita sejumlah peserta. Boneka tangan dan buku cerita mengambil tema Binatang yang lebih dekat dengan dunia anak-anak.

\section{Pelaksanaan Pendampingan}

Aksi pendampingan pada penelitian ini adalah dengan memberikan pendampingan terhadap orang tua dan guru di KB Al Naba dengan meningkatkan kemampuan mendongeng menggunakan media buku cerita dan boneka tangan.

Pendampingan dilaksanakan pada Hari Minggu tanggal 22 September 2019 bertempat di KB Al Naba pada pukul 8.00 - 12.00 WIB dengan jadwal sebagai berikut :

\section{a. Pembukaan (8.00 - 08.30)}

Acara pembukaan di buka oleh Ibu Iis Sa'diyyah dengan membaca Suratul Fatihah.

Acara selanjutnya adalah sambutan oleh ibu Kepala KB Al Naba, Lilis Puspitosari S.P. Ibu Kepala KB Al Naba menyampaikan terima kasih yang sebesar-besarnya kepada LP2M IAIN Tulungagung atas terselenggaranya acara Pendampingan Orang Tua dan Guru di KB Al Naba dengan harapan dapat meningkatkan kemampuan orangtua dan guru dalam mendongeng menggunakan boneka tangan. Ibu Kepala KB Al Naba juga menyampaikan terima kasih kepada para orang tua yang dengan sangat antusias menghadiri acara ini, juga kepada Tim Guru yang membantu terlaksananya acara ini dengan baik.

Ibu kepala juga menyampaikan bahwa para orangtua jangan terlalu memaksakan kepada anaknya untuk supaya cepat bisa membaca, karena yang terpenting adalah bagaimana anak tertarik dan suka untuk memegang buku. Memberi stimulasi sangat penting supaya tumbuh minat baca pada anak salah satunya dengan mendongeng. Harapan ibu Kepala KB Al Naba setelah acara pendampingan ini orang tua dan guru meningkat kemampuan mendongengnya sehingga anak-anak juga semakin termotivasi untuk meningkatkan budaya membaca permulaan.

\section{b. Acara Inti (08.30-11.30)}

Acara inti terbagi atas 2 sesi, yang pertama adalah sesi pemberian materi dan sesi praktek. Sesi pemberian materi diisi oleh Peneliti dan Kak Dewi Mora dari Ikatan Penulis Muslim.

Peneliti memberikan materi tentang pentingnya meningkatkan budaya membaca permulaan bagi anak usia dini. Faktor utama yang biasanya menyebabkan minat baca masyarakat Indonesia masih rendah adalah karena kebiasaan membaca yang belum ditanamkan sejak anak usia dini. Role model anak di keluarga adalah anak-anak akan 
mengikuti kebiasaan dari orang tua artinya bahwa orang tua haruslah menjadi figur. Oleh karena itu, peranan orang tua untuk mengajarkan kebiasaan membaca adalah penting dalam meningkatkan kemampuan literasi anak.

Peneliti juga menjelaskan tentang pentingnya mendongeng bagi anak yaitu : 1) Perkembangan kognitif, melalui kisah-kisah dongeng, anak mendapatkan berbagai informasi, anak juga dapat mempelajari sebab akibat serta belajar menganalisa sehingga pemikiran anak menjadi lebih baik, lebih kritis dan cerdas. Anak juga bisa memahami hal mana yang perlu ditiru dan tidak boleh. 2) Perkembangan sosial dan emosional, kita bisa menyelipkan ajaran normanorma seperti sosial, agama dan sopan santun, 3) Memperat ikatan anak dan orang tua, dengan mendongeng, orang tua berdekatan secara intim, komunikasi efektif pun berjalan dengan baik. 4) . mengembangkan daya imajinasi Dunia anak adalah dunia imajinasi. Anak memiliki dunia sendiri dan tak jarang mereka berbicara dengan teman khayalannya. Dengan daya imajinasi yang masih sangat bagus ini, maka orang tua harus bisa mengarahkannya ke arah yang positif dan tetap terkontrol. Anak yang kurang imajinasi bisa berakibat pada pergaulan yang kurang, sulit bersosialisasi atau beradaptasi dengan lingkungan yang baru, 5) Meningkatkan keterampilan berbahasa, dengan memberikan stimulasi dini yang mampu merangsang keterampilan berbahasa pada anak-anak. Kisah-kisah dongeng yang mengandung cerita positif tentang perilaku membuat anak-anak menjadi lebih mudah dalam menyerap tutur kata yang sopan, 6) membangkitkan minat baca, dengan memberikan cerita dongeng pada anak-anak, mereka akan tertarik dan penasaran untuk mencari tahu. Inilah dimana keinginan untuk membaca semakin meningkat.

Kak Dewi Mora memberikan materi tentang bagaimana caranya orang tua bisa bercerita kepada anak. Yang pertama kali diingatkan bahwa setiap anak itu unik, jadi orang tua tidak diperbolehkan membandingkan anak sendiri dengan anak orang lain. Yang kedua adalah bahwa sebelum orang tua membacakan cerita kepada anak, terlebih dahulu membaca buku tersebut sehingga bisa memahami karakter yang ada di dalam buku cerita tersebut. Yang ketiga, supaya menarik maka setiap karakter bisa didengarkan dengan suara yang berbeda. Untuk suara binatang biasanya gajah memiliki suara yang berat, kelinci cenderung manja dan centil dan seterusnya, dan yang terakhir adalah pentingnya ekspresi. Jangan sampai orangtua menceritakan tentang kisah yang sedih tetapi ekspresinya tertawa. Kak Dewi Mora mengeluarkan boneka kesayangannya yang bernama Igos dan memberi contoh bagaimana mendongeng kepada anak dengan media boneka.

Orangtua dan guru praktek menirukan suara-suara hewan yang berbeda setelah itu belajar cara 
menggunakan boneka tangan sambil bercerita kepada anaknya. Orang tua dan guru praktek berpasangan bagaimana belajar mengungkapkan ekspresi marah, sedih dan bahagia. Orang tua sangat antusias mempraktekkannya, sementara anakanak yang diajak pada acara pendampingan juga ikut antusias.

Kak Dewi mengakhiri acara dengan sesuatu yang pasti membuat anak tertarik untuk memperhatikan yaitu menunjukkan sulap.

\section{c. Penutup (11.30-12.00)}

Acara pendampingan di tutup dengan pembacaan doa oleh ibu Iis Sadiyyah dengan harapan semoga acara pendampingan ini membawa manfaat yang besar bagi orang tua, guru dan terutama bagi anak.

Sebelum peserta pendampingan pulang seluruh peserta berfoto bersama dengan Kak Dewi Mora, Peneliti, Asisten dan seluruh Guru KB Al Naba

\section{Monitoring dan Evaluasi}

Acara Monitoring dan evaluasi dilaksanakan di Warung 22 Arjowinangun Malang pada tanggal 11 Oktober 2019 jam 10.30 yang menghadirkan beberapa orangtua dan guru KB Al Naba.

$\mathrm{Bu}$ lis mengungkapkan bahwa anak-anak menjadi lebih tertarik untuk mendengarkan cerita, anakanak juga menjadi lebih tertib dan tenang dalam proses belajar mengajar di sekolah

$\mathrm{Bu}$ Us sebagai orangtua dari ananda Aqilla mengungkapkan bahwa menggunakan boneka tangan masih kesulitan tetapi untuk buku cerita, anaknya sangat tertarik. Anaknya selalu membawa kemana saja buku cerita tersebut dan bisa menceritakan sendiri gambar di dalamnya kepada orang lain atau kakaknya.

$\mathrm{Bu}$ Arin mengungkapkan bahwa kesulitan terbesar dalam mempraktekkan dongeng yang kemarin adalah merubah suara, misalnya antara suara A yang besar ke suara B yang kecil dan seterusnya, biasanya pada awal cerita masih bisa konsisten tetapi akhirnya rancu antara suara tersebut.

Beberapa hal yang menjadi usulan untuk program berikutnya adalah:

a. Pendampingan bisa dilaksanakan dalam skala yang lebih luas, misalnya tingkat Gugus atau bahkan tingkat Kecamatan

b. Untuk materi dongeng selain tentang binatang bisa tentang dongeng nusantara dan juga tentang kisah Nabi/Rosul

c. Perlu adanya pelatihan lagi tentang teknik merubah suara dan ekspresi pendongeng

\section{Kesimpulan}

Kegiatan pendampingan berjalan dengan lancar dihadiri oleh 40 peserta terdiri dari 30 orang wali murid, 4 guru KB Al Naba, dan 6 guru PAUD disekitar KB Al Naba . Peserta pendampingan terlihat antusias dengan materi 
pendampingan yang diberikan. Hal ini terlihat dari awal hingga akhir acara, semua peserta mengikuti dengan baik.

Hasil dari monitoring adalah peserta didik menjadi lebih tertarik untuk mendengarkan dongeng, lebih tertib dan tenang dalam proses belajar mengajar di KB Al Naba. Beberapa anak tertarik pada buku cerita dan bisa menceritakan cerita bergambar sendiri.

\section{E. Rekomendasi}

Harapannya kegiatan pendampingan ini bisa dilaksanakan dalam skala yang lebih luas dengan materi yang lebih berkembang yaitu tentang cara membuat suara yang berbeda, ekspresi wajah serta mengenal kisah Sejarah dan kisah kepahlawanan kepada anak.

\section{Referensi}

Darwadi 2002 dalam Nurfalah, Upaya Meningkatkan Kemampuan Membaca Permulaan Melalui Pendekatan Proses pada Siswa Kelas II SDN 1 Wosu Kec. Bungku Barat Kab. Morowali, Jurnal Kreatif Tadulako Online Vol. 3 No. 1, hal 31

Mety Toding Bua, Anang Santoso, Muakibatul Hasanah, Jurnal Pendidikan, Vol. 1, No. 9, Bln September, Thn 2016, Hal 17491752

Nana Sudjana dan Ahmad Rivai. Media Pengajaran.Bandung: Sinar Baru Algensindo.(2002:188).

Oliver, Serrat, Storytelling.2008. United States of America: ReedElsevier

Pradipta, G. A. (2011). Keterlibatan orang tua dalam proses mengembangkan literasi dini anak usia paud di Surabaya. Jurnal Unair,1(3),1-9.
Suyadi. (2010). Psikologi Belajar Anak Usia Dini. Yogyakarta : PEDAGOGIA

Widyaning Hapsari, Lisnawati Ruhaena, \& Wiwien Dinar Pratisti , Peningkatan Kemampuan Literasi Awal Anak Prasekolah melalui Program Stimulasi, Jurnal Psikologi. Volume 44, Nomor 3, 2017: hal 178

W.J.S Poerwadarminta,1984, Kamus Umum Bahasa Indonesia, Jakarta. PN Balai. Pustaka

Media Online :

Jumlah Data Satuan Pendidikan (Sekolah) Anak Usia Dini Per Kabupaten/Kota : Kota Malang online http://referensi.data.kemdikbud.go.id /index21.php?kode $=056100 \&$ level $=$ $\underline{2}$

Kompas.com "Manfaat Dongeng untuk Anak", https://lifestyle.kompas.com/read/20 12/05/15/14183692/manfaat.dongen g.untuk.anak.

Nurul Iswari. (2017). Ini Penyebab Rendahnya Minat Baca di Indonesia. Media Online Kumparan, https://kumparan.com/nuruliswari/ini-penyebab-rendahnyaminat-baca-di-indonesia1504967041086. Diakses 20 Juli 2019.

Winda Destiana Putri. Peran Penting Mendongeng untuk Anak dan Orangtua, 8 Juli 2019 13:36 WIB https://www.republika.co.id/berita/g ayahidup/parenting/15/02/25/nkbbl2peran-penting-mendongeng-untukanak-dan-orangtua 